Article

\title{
The First Occurrence of Asbestiform Magnesio-Riebeckite in Schists in the Frido Unit (Pollino Unesco Global Geopark, Southern Italy)
}

\author{
Salvatore Laurita and Giovanna Rizzo *D \\ Department of Sciences, University of Basilicata, Campus di Macchia Romana, Viale dell'Ateneo Lucano 10, \\ 85100 Potenza, Italy \\ * Correspondence: giovanna.rizzo@unibas.it; Tel.: +39-0971-20-5833
}

Received: 22 July 2019; Accepted: 29 August 2019; Published: 31 August 2019

check for updates

\begin{abstract}
In this paper, new mineralogical and petrographical data of asbestiform Magnesio-riebeckite from ophiolite cropping out in the Pollino Unesco Global Geopark (southern Italy) are presented. Magnesio-riebeckite schists with HP-LT index mineral assemblage recorded metamorphic events in blueschist facies in the Frido Unit. Previous toxicological studies showed that asbestiform Magnesio-riebeckite species exhibited high carcinogenicity in previous intraperitoneal injection experiments with rats. The results have been obtained using different analytical techniques such as X-ray fluorescence (XRF), scanning electron microscopy with energy dispersive spectroscopy (SEM-EDS), and electron probe micro analysis (EPMA). Results show that all the samples contain fibrous Magnesio-riebeckite and/or prismatic, acicular crystals in aggregates. The concentration of elements in Magnesio-riebeckite crystals is: $\mathrm{Na}_{2} \mathrm{O}(4.12-6.26 \mathrm{wt} \%), \mathrm{MgO}(8.22-10.87 \mathrm{wt} \%), \mathrm{FeO}$ (19.07-23.81 wt\%), $\mathrm{SiO}_{2}$ (52.05-56.06 wt\%), $\mathrm{CaO}(1.12-4.53 \mathrm{wt} \%), \mathrm{Al}_{2} \mathrm{O}_{3}(1.34-1.93 \mathrm{wt} \%)$, and $\mathrm{MnO}$ $(0.10-0.34 \mathrm{wt} \%)$. Magnesio-riebeckite crystals are documented in the Pollino Unesco Global Geopark for the first time. For this reason, the aim of this paper is the characterization of Magnesio-riebeckite to improve the knowledge of this mineral in the studied area, because the release of fibers into the environment is dangerous for human health.
\end{abstract}

Keywords: magnesio-riebeckite; asbestos minerals; schists; blueschist facies; Pollino Unesco Gobal Geopark

\section{Introduction}

The problem of toxicity and carcinogenicity of asbestos minerals has long been discussed since the 20 century, because it represents a clear consequence for human health. The term asbestos represents a series of six natural asbestiform silicate minerals, which include serpentine (chrysotile), as well as amphibole minerals (tremolite, actinolite, anthophyllite, amosite, and crocidolite that represent a variety of commercial term of fibrous riebeckite) that are defined by law in Europe and in several countries worldwide [1-4] and also by Italian law (D.Lgs. 2008). Asbestos minerals are flexible, heat-resistant, and chemically inert. These minerals usually occur with an elongated, prismatic, acicular, or fibrous habit, which can be easily separable in thin fibers and can be inhaled up the respiratory tract. Asbestos fibers, when present in natural geologic outcrops, can be defined as naturally occurring asbestos (NOA) [5,6]. In Basilicata, NOA are mainly concentrated in the ophiolitic sequences cropping out in Pollino Unesco Global Geopark (southern Italy) [2,4,7]. In this area, the most common types of asbestos are serpentine and tremolite, and in a recent study, also edenite [2]. The structure of amphiboles minerals is characterized by the presence of $\mathrm{Si}^{4+}$ and $\mathrm{Al}^{3+}$ in the tetrahedral site that form double chains running parallel to c-axis, forming columnar and fibrous crystals. Magnesio-riebeckite is a monoclinic 
$(\mathrm{C} 2 / \mathrm{m})$ sodic amphibole with ideal formula $\mathrm{Na}_{2} \mathrm{Fe}_{2}{ }^{3+}\left(\mathrm{Fe}^{2+}, \mathrm{Mg}\right)_{3}\left[\mathrm{SiO}_{8} \mathrm{O}_{22}(\mathrm{OH})_{2}\right][8,9]$. The name 'riebeckite' was first used by [10] in order to describe a blackish amphibole in Socotra (Yemen) by Dr. E. Riebeck. In the schist of the Frido Unit, in addition to the prismatic variety, the crystals of Magnesio-riebeckite is very common, and shows fibrous habit comparable with size (length $\geq 5 \mu \mathrm{m}$ and width $<3 \mu \mathrm{m}$ with aspect ratio $>3: 1$ ), as defined by Directive 2003/18/CE. In terms of geometrical feature, morphology, and size, it belongs to the regulated asbestos minerals, together with chrysotile, tremolite, actinolite, anthophyllite, and amosite. Riebeckite also occurs in mossy aggregate or in fibrous habits. The term "blue asbestos" refers to the blue, highly fibrous variety. The crystallographic structure of riebeckite consists of double chains of corner-sharing $\mathrm{T}(1,2)$ tetrahedra occupied by Si and strips of edge-sharing $\mathrm{M}(1,2,3)$ octahedra occupied by $\mathrm{Mg}^{2+} \mathrm{Fe}^{2+}$ and $\mathrm{Fe}^{3+}$, both of which extend in the c-direction.

The release of Magnesio-riebeckite fibers in the study area is the result of weathering processes and human activities, such as road construction, causing one or more respiratory diseases for the people that are living in proximity of a naturally occurring asbestos area. For this reason, the crystal chemical characterization of Magnesio-riebeckite in the schists of the Frido Unit is extremely relevant for environmental and health issues. Furthermore, this study may provide new information for the Italian mapping of natural sites that are characterized by the presence of the asbestos minerals in the Pollino Unesco Global Geopark.

\section{Geological Outline}

The study area is located in the Southern Apennines, northeast of Pollino Unesco Global Geopark (Figure 1a). The ophiolite-bearing terranes described as Liguride Complex [11,12] have been interpreted as remnants of an accretionary wedge developed between the Calabria terrane and Apulian platform involved in the orogenic wedge during the Neogene time [13]. It has been subdivided into different tectono-metamorphic units. From bottom to top, it consists of the blueschist Frido Unit, the Episcopia-San Severino Mélange, and non-metamorphic North Calabrian Unit $[2,14,15]$ (Figure 1b). The Frido Unit represents the uppermost unit of the ophiolite-bearing terranes [16], and mainly consists of polydeformed sequence, including blocks of oceanic and continental type rocks, and metasediments [13,17-22]. The ophiolite sequence from the Frido Unit consists of basalts and tectonized serpentinites containing blocks of metabasites, and rodingites [7,17,21,23-29], foliated metabasites [30], and metapillow lava [31]. Serpentinites result from serpentinization of mantle peridotites, that show porphyroclastic texture $[7,25,28]$. Bodies of continental crust rocks, generally overlying slices of serpentinites [17,21] (Figure 1b), are mainly composed of altered garnet gneisses, garnet biotitic gneisses, and leucocratic gneisses and gneisses with albitic veins $[17,32]$. The mineral assemblages in the rocks of the Frido Unit show a polyphase HP metamorphism, overprinted by a lower pressure greenschist facies metamorphism [33]. Overprinting high-pressure metamorphism is related to early Alpine event [17]. For the blueschist facies, pressure ranged between 8 to $12 \mathrm{kbar}$ and temperatures are $350 \pm 50^{\circ} \mathrm{C}$ [34], with a geothermal gradient of $8{ }^{\circ} \mathrm{C} / \mathrm{km}$ [35]. 


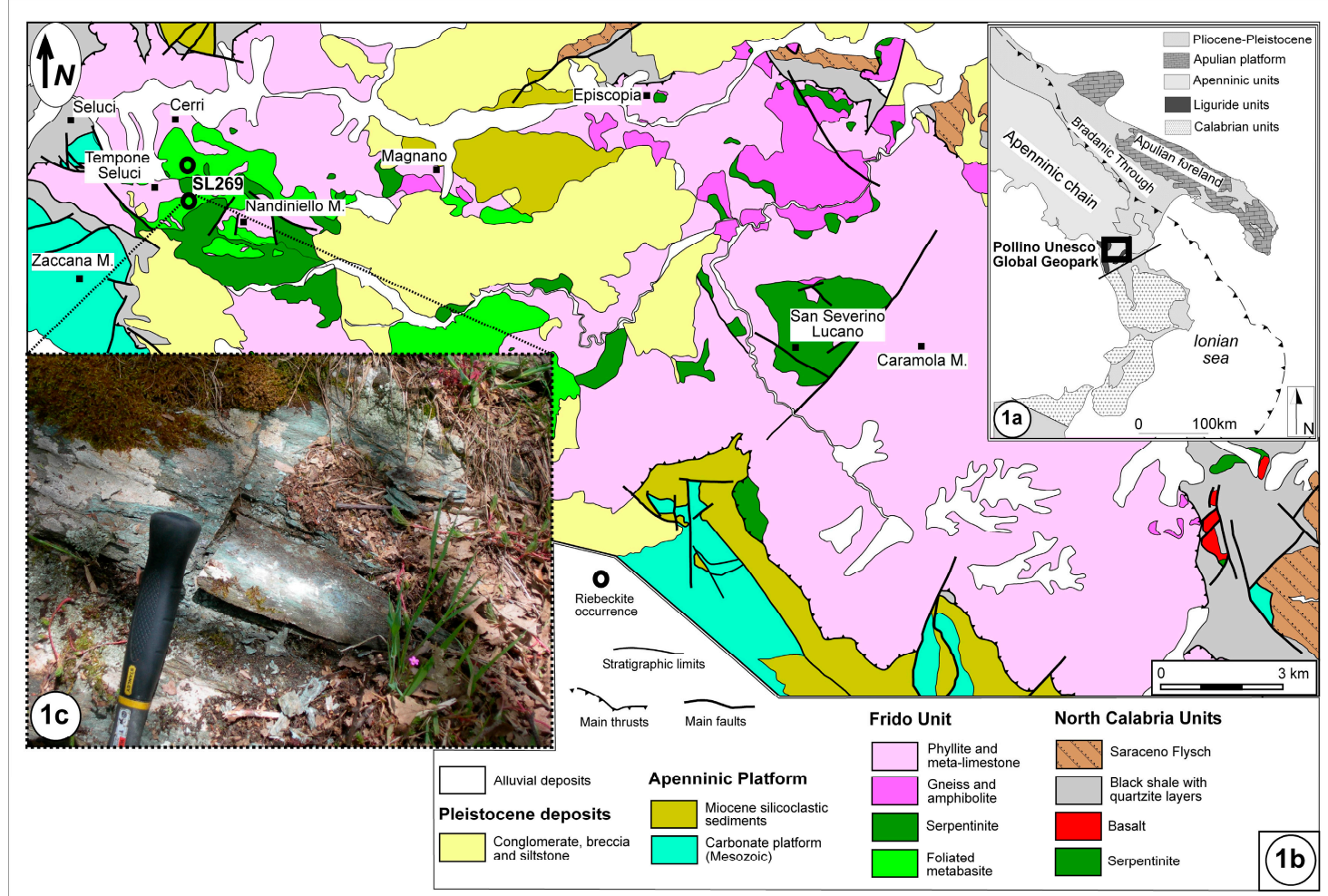

Figure 1. (a) Simplified tectonic sketch of the southern Apennines; (b) geological map of the northeast area of Pollino Unesco Global Geopark with samples site; (c) outcrop of mylonitic green Mg-riebeckite schists associated to foliated metabasites.

\section{Sampling and Analytical Methods}

Twelve riebeckite schist specimens associated with foliated metabasites were collected in the Mount Nandiniello area in the Pollino Unesco Global Geopark (Figure 1b). Three representative samples were georeferenced with GPS system and were selected for X-ray Fluorescence, SEM-EDS,

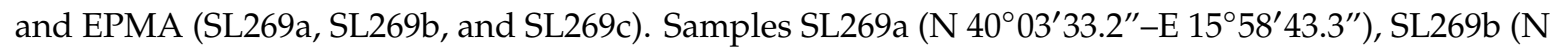
$\left.40^{\circ} 03^{\prime} 12.3^{\prime \prime}-\mathrm{E} 15^{\circ} 45^{\prime} 33.3^{\prime \prime}\right)$, and SL269c (N 40 $\left.02^{\prime} 42.9^{\prime \prime}-\mathrm{E} 15^{\circ} 20^{\prime} 8.8^{\prime \prime}\right)$, are fine-grained, strongly foliated, and with mylonitic texture (Figure 1c). Petrographic observation was carried out by optical polarizing microscopy $(\mathrm{OM})$, using a ZEISS microscopy, on thin sections of rocks. The chemical characterization of whole-rock was performed using an X-ray fluorescence (XRF BRUKER S8-TIGER) at the Department of Biology, Ecology, and Earth Sciences (DiBEST), University of Calabria (Arcavacata di Rende, Cosenza, Italy). Elemental analyses for major ( $\mathrm{wt} \%: \mathrm{SiO}_{2}, \mathrm{TiO}_{2}, \mathrm{Al}_{2} \mathrm{O}_{3}, \mathrm{Fe}_{2} \mathrm{O}_{3}, \mathrm{MnO}, \mathrm{MgO}, \mathrm{CaO}, \mathrm{Na}_{2} \mathrm{O}, \mathrm{K}_{2} \mathrm{O}$, and $\mathrm{P}_{2} \mathrm{O}_{5}$ ) and some trace elements (ppm: $\mathrm{Ni}, \mathrm{Co}, \mathrm{Cr}, \mathrm{V}, \mathrm{Sc}, \mathrm{Zn}, \mathrm{Cu}, \mathrm{Rb}, \mathrm{Sr}, \mathrm{Y}, \mathrm{Zr}, \mathrm{Nb}, \mathrm{Ba}, \mathrm{La} \mathrm{Ce}, \mathrm{Th}$, and Pb) concentrations were obtained at the Department of Biology, Ecology, and Earth Science, University of Calabria (Arcavacata di Rende-Cosenza, Italy) using XRF PHILIPS PW-1480 and following the matrix correction methods by [36,37]. The structural water was removed from sample powders by heating at $1030{ }^{\circ} \mathrm{C}$ for $1 \mathrm{~h}$. Loss on ignition (LOI) was determined from the total weight change. SEM-EDS analyses were performed on the polished thin sections at the Istituto di Metodologie per 1'Analisi Ambientale (CNR-Tito scalo, Potenza, Italy), using a FESEM ZEISS SUPRRA 40 Oxford INCA scanning microscope with detector X ACT SSD; analytical conditions were 3 to $20 \mathrm{kV}$ accelerating voltage and WD from 3 to 8.5. Electron probe micro analysis were performed on Magnesio-riebeckite crystals, using a JEOL JXA-8200 probe, in wavelength-dispersive mode with $15 \mathrm{kV}$ acceleration potential, $20 \mathrm{nA}$ beam current, and a counting time of $20 \mathrm{~s}$ at the Freie Universität of Berlin. Natural and synthetic minerals were used for standardization. 


\section{Previous Studies of Asbestos Minerals in the Pollino Unesco Global Geopark}

The presence of NOA in ophiolite rocks had been documented in the Pollino Unesco Global Geopark [4,7]. Previous studies on serpentinite rocks highlighted that they are made up of fibrous minerals accounting for $55 \%$ of the total mineral composition [2]. The serpentinites have been characterized using different analytical techniques $\mu$-Raman spectroscopy, FT-IR spectroscopy, SEM-EDS, and EPMA (electron probe micro analysis), and confirmed the presence of serpentine and amphibole group minerals (lizardite, chrysotile, antigorite, and tremolite-actinolite) [7]. In addition, [2] revealed for the first time the occurrence of edenite in the serpentinite rocks of the Frido Unit. Bloise et al. (2019) showed that in the geographic area near Episcopia (Pollino Unesco Global Geopark), significant health problems are NOA-correlated.

\section{Results and Discussion}

In addition to asbestos serpentine, tremolite, and edenite described in other works $[2,4,7,28]$, in ophiolite rocks from the Frido Unit (Pollino Unesco Global Geopark), a presence of fibrous Magnesio-riebeckite has been detected in schists. Samples analyzed by optical microscopy shows that the schists cropping out close to the Mount Nandiniello area in the Pollino Unesco Global Geopark are fine-grain foliated rocks and mainly consist of Magnesio-riebeckite, glaucophane, epidote, stilpnomelane, quartz, and chlorite. The schists exhibit evidence of a very pervasive deformation, as indicated by the preferred orientation of Magnesio-riebeckite, glaucophane, chlorite, and stilpnomelane. Magnesio-riebeckite occurs as elongated prismatic fibrous or radial fibrous aggregates (Figure 2a,b) with dark green-blue color and vitreous luster. Glaucophane is light blue to deep bluish violet with strong pleochroism and occur as prismatic crystals in the matrix. Epidote crystals have a subidioblastic habit and are found in matrix. Subidioblastic stilpnomelane crystals are present along the main schistosity and are associated with the other crystals along the main foliation (Figure 2a). Quartz grains commonly show undulose extinction and recrystallization to smaller new grain aggregate. Chlorite crystals occur as fibrous-radiated aggregates and form the schistosity (Figure 2b). Two generations of chlorite are observed, one coarse-grained and the latter are oriented parallel to the foliation with the main assemblage and are also a product of the breakdown of Na-amphiboles.
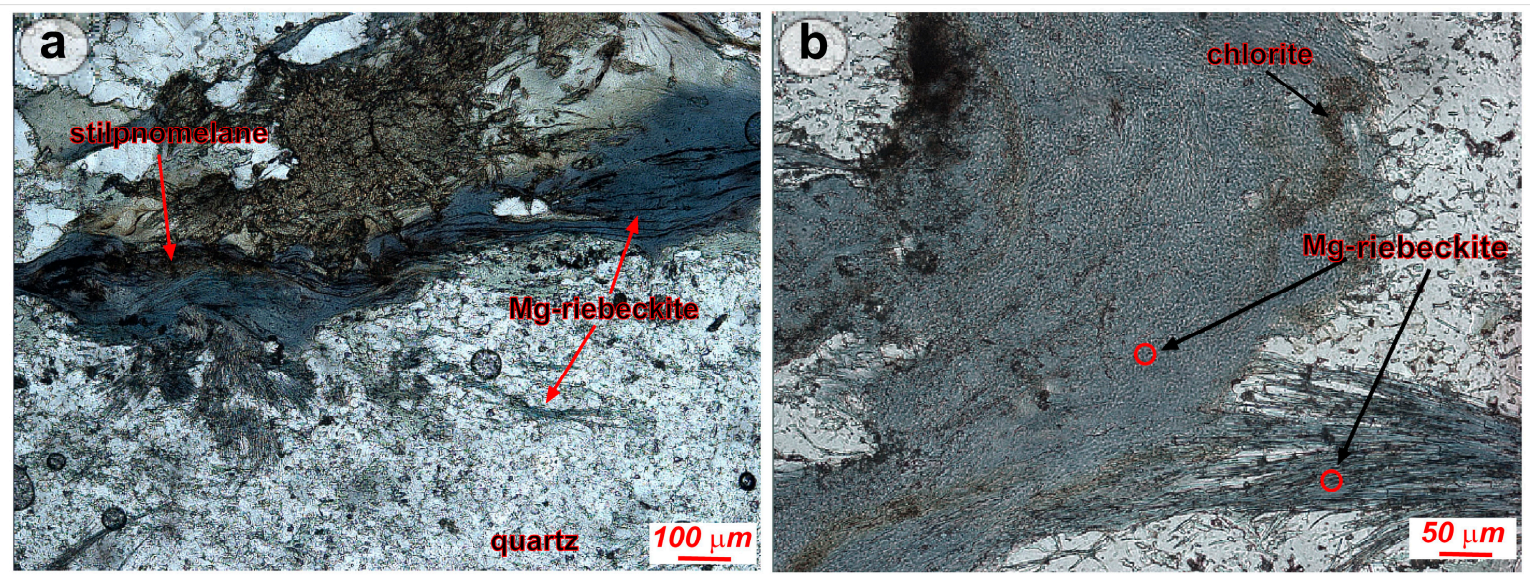

Figure 2. Photomicrographs of Mg-riebeckite schists (crossed polars); (a) Magnesio-riebeckite and stilpnomelane crystals along the main schistosity; (b) chlorite crystals occur as fibrous-radiated aggregates along the schistosity. (The small red circles indicate the position of point analysis with electron probe micro analysis (EPMA)).

Whole-rock chemical analyses for investigated samples are reported in Table 1. X-ray fluorescence analyses suggest relatively homogeneous compositions between the three samples. Major element data show that $\mathrm{SiO}_{2}$ is the dominant oxide ( 55.00 to $56.87 \mathrm{wt} \%$ ), followed by $\mathrm{Al}_{2} \mathrm{O}_{3}$ (16.66 to $17.03 \mathrm{wt} \%$ ), $\mathrm{Fe}_{2} \mathrm{O}_{3}(8.26$ to $9.20 \mathrm{wt} \%), \mathrm{MgO}(6.47$ to $7.00 \mathrm{wt} \%)$, and $\mathrm{Na}_{2} \mathrm{O}$ (7.66 to $\left.8.01 \mathrm{wt} \%\right)$. Concentrations of 
the other major elements are low. In order to testify the occurrence of Magnesio-riebeckite fibrous crystals, we made morphological investigation with scanning electron microscope and microanalytical investigation (EDS analyses) on single crystals of amphiboles. Results showed that the crystals have Magnesio-riebeckite composition.

Table 1. Major and minor elements abundances of schists of the Frido Unit in the Pollino Unesco Global Geopark. (n.d. = not detected).

\begin{tabular}{|c|c|c|c|}
\hline Sample & SL269a & SL269b & SL269c \\
\hline \multicolumn{4}{|c|}{ Oxides (wt $\%$ ) } \\
\hline $\mathrm{SiO}_{2}$ & 56.87 & 55.00 & 55.34 \\
\hline $\mathrm{TiO}_{2}$ & 0.75 & 0.82 & 0.80 \\
\hline $\mathrm{Al}_{2} \mathrm{O}_{3}$ & 16.66 & 17.00 & 17.03 \\
\hline $\mathrm{Fe}_{2} \mathrm{O}_{3}$ tot & 8.26 & 9.00 & 9.20 \\
\hline $\mathrm{MnO}$ & 0.12 & 0.10 & 0.13 \\
\hline $\mathrm{MgO}$ & 6.47 & 7.00 & 6.90 \\
\hline $\mathrm{CaO}$ & 0.9 & 0.82 & 0.93 \\
\hline $\mathrm{Na}_{2} \mathrm{O}$ & 7.66 & 8.01 & 7.90 \\
\hline $\mathrm{K}_{2} \mathrm{O}$ & n.d. & 0.2 & 0.4 \\
\hline $\mathrm{P}_{2} \mathrm{O}_{5}$ & 0.06 & 0.09 & 0.07 \\
\hline LOI & 2.25 & 1.96 & 1.3 \\
\hline Sum & 100 & 100 & 100 \\
\hline \multicolumn{4}{|l|}{$\mathrm{ppb}$} \\
\hline $\mathbf{N i}$ & 0.203 & 0.210 & 0.204 \\
\hline Co & 0.107 & 0.110 & 0.109 \\
\hline $\mathrm{Cr}$ & 0.118 & 0.130 & 0.120 \\
\hline $\mathbf{V}$ & 0.117 & 0.120 & 0.119 \\
\hline Sc & 0.028 & 0.025 & 0.030 \\
\hline $\mathrm{Zn}$ & 0.315 & 0.29 & 0.30 \\
\hline $\mathrm{Cu}$ & 0.239 & 0.241 & 0.237 \\
\hline $\mathbf{R b}$ & 0.216 & 0.220 & 0.218 \\
\hline $\mathrm{Sr}$ & 0.039 & 0.037 & 0.040 \\
\hline$Y$ & 0.132 & 0.133 & 0.132 \\
\hline $\mathrm{Zr}$ & 0.985 & 0.985 & 0.987 \\
\hline $\mathrm{Nb}$ & 0.076 & 0.08 & 0.078 \\
\hline $\mathbf{B a}$ & 0.0004 & 0.0002 & 0.0003 \\
\hline La & 0.0081 & 0.009 & 0.008 \\
\hline $\mathrm{Ce}$ & 0.0151 & 0.014 & 0.015 \\
\hline Th & 0.013 & 0.014 & 0.011 \\
\hline $\mathbf{P b}$ & 0.0051 & 0.005 & 0.0053 \\
\hline
\end{tabular}

SEM images of the Magnesio-riebeckite evidence the presence of fibrous minerals with acicular and also lamellar habit. Fiber sizes are approximately between 5-20 $\mu \mathrm{m}$ in length and have diameters of about $1 \mu \mathrm{m}$. Representative images of Magnesio-riebeckite fibers are reported in Figure 3a-c. EDS chemical analysis (Figure 3) showed the presence of a substantial amount of Fe; in fact, crocidolite is among amphibole asbestos, one of the richest in iron [38]. Fe catalyze generation of reactive oxygen species (ROS) [39-41], and therefore is important for asbestos toxicity. 

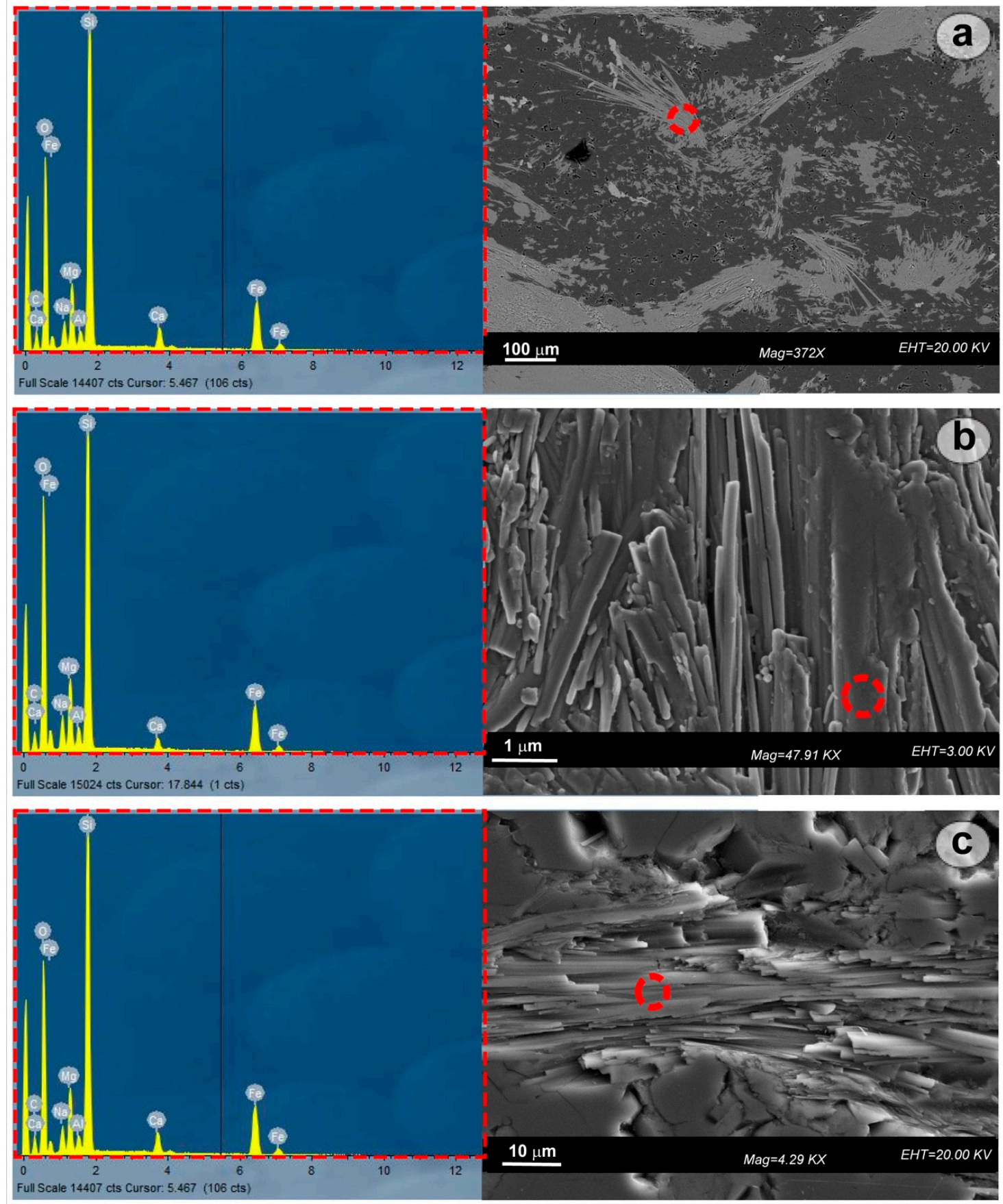

Figure 3. SEM images and relative point analysis of asbestos (a) and acicular/lamellar $(\mathbf{b}, \mathbf{c})$ Magnesio-riebeckite.

Crystals of sodium amphibole don't show zoning and compositional variation. Microprobe analysis of amphibole crystals are reported in Table 2. 
Table 2. Representative EPMA analyses of selected fibrous Magnesio-riebeckite crystals in the schists from the Frido Unit in the Pollino Unesco Global Geopark. (n.d. = not detected).

\begin{tabular}{ccccccccccc}
\hline $\begin{array}{c}\text { Number of } \\
\text { Analyses }\end{array}$ & $\mathbf{2 6 9 - 5}$ & $\mathbf{2 6 9 - 4}$ & $\mathbf{2 6 9 - 4 a}$ & $\mathbf{2 6 9 - 3}$ & $\mathbf{2 6 9 - 3 a}$ & $\mathbf{2 6 9 - 2 a 8}$ & $\mathbf{2 6 9 - 4 b}$ & $\mathbf{2 6 9 - 1}$ & $\mathbf{2 6 9 - 1 a}$ & $\mathbf{2 6 9 - 1 1}$ \\
\hline $\mathrm{SiO}_{2}$ & 54.1 & 54.97 & 54.81 & 55.60 & 55.39 & 54.48 & 54.90 & 54.83 & 54.74 & 52.52 \\
$\mathrm{TiO}_{2}$ & 0.12 & 0.10 & 0.06 & 0.04 & 0.04 & 0.08 & 0.08 & 0.23 & 0.11 & 0.18 \\
$\mathrm{Al}_{2} \mathrm{O}_{3}$ & 1.34 & 1.43 & 1.55 & 1.39 & 1.58 & 1.31 & 1.52 & 2.26 & 1.52 & 1.93 \\
$\mathrm{FeO}$ & 22.08 & 22.57 & 22.90 & 22.14 & 22.78 & 21.41 & 22.18 & 21.39 & 22.49 & 23.81 \\
$\mathrm{MnO}$ & 0.34 & 0.10 & 0.20 & 0.28 & 0.32 & 0.33 & 0.22 & 0.13 & 0.15 & 0.20 \\
$\mathrm{MgO}$ & 9.75 & 9.24 & 8.87 & 9.79 & 9.01 & 10.08 & 9.14 & 8.33 & 9.08 & 8.79 \\
$\mathrm{CaO}$ & 3.93 & 3.03 & 2.07 & 3.98 & 2.25 & 4.32 & 3.07 & 1.12 & 2.41 & 2.90 \\
$\mathrm{Na}{ }_{2} \mathrm{O}$ & 4.66 & 5.01 & 5.62 & 4.70 & 5.47 & 4.60 & 5.09 & 6.02 & 5.29 & 4.61 \\
$\mathrm{~K}_{2} \mathrm{O}$ & 0.07 & 0.06 & 0.03 & 0.05 & 0.05 & 0.05 & 0.02 & 0.08 & 0.10 & 0.05 \\
$\mathrm{Cr}_{2} \mathrm{O}_{3}$ & $n . d$. & 0.04 & 0.09 & $n . d$. & $n . d$. & $n . d$. & 0.03 & $n . d$. & 0.02 & 0.02 \\
$\mathrm{Sum}$ & 96.40 & 96.56 & 96.21 & 97.96 & 96.90 & 96.66 & 96.24 & 97.13 & 96.64 & 95.00 \\
\hline $\mathrm{Si}$ & 7.90 & 7.99 & 7.99 & 7.98 & 8.00 & 7.93 & 8.01 & 8.09 & 7.99 & 7.75 \\
$\mathrm{Ti}$ & 0.01 & 0.01 & 0.01 & 0.00 & 0.00 & 0.01 & 0.01 & 0.03 & 0.01 & 0.02 \\
$\mathrm{Al}$ & 0.23 & 0.24 & 0.27 & 0,23 & 0.27 & 0.23 & 0.26 & 0.39 & 0.26 & 0.33 \\
$\mathrm{Fe}{ }^{3+}$ & 1.39 & 1.39 & 1.51 & 1.26 & 1.49 & 1.24 & 1.30 & 1.28 & 1.47 & 1.88 \\
$\mathrm{Fe}^{2+}$ & 1.31 & 1.35 & 1.28 & 1.39 & 1.26 & 1.37 & 1.41 & 1.36 & 1.27 & 1.05 \\
$\mathrm{Mn}$ & 0.04 & 0.01 & 0.02 & 0.03 & 0.04 & 0.04 & 0.03 & 0.02 & 0.02 & 0.02 \\
$\mathrm{Mg}$ & 2.12 & 2.00 & 1.93 & 2.09 & 1.94 & 2.19 & 1.99 & 1.83 & 1.98 & 1.93 \\
$\mathrm{Ca}$ & 0.61 & 0.47 & 0.32 & 0.61 & 0.35 & 0.67 & 0.48 & 0.18 & 0.38 & 0.46 \\
$\mathrm{Na}$ & 1.32 & 1.41 & 1.59 & 1.31 & 1.53 & 1.30 & 1.44 & 1.72 & 1.50 & 1.32 \\
$\mathrm{~K}$ & 0.01 & 0.01 & 0.01 & 0.01 & 0.01 & 0.01 & 0.00 & 0.01 & 0.02 & 0.01 \\
\hline $\mathrm{XMg}$ & 0.62 & 0.60 & 0.60 & 0.60 & 0.61 & 0.62 & 0.59 & 0.57 & 0.61 & 0.65 \\
$\mathrm{XFe}{ }^{3+}$ & 0.91 & 0.85 & 0.85 & 0.85 & 0.85 & 0.88 & 0.83 & 0.76 & 0.85 & 0.95 \\
$\mathrm{XFe}{ }^{2+}$ & 0.38 & 0.40 & 0.40 & 0.40 & 0.39 & 0.38 & 0.41 & 0.42 & 0.39 & 0.35 \\
\hline & & & & & & & & & &
\end{tabular}

The amphibole structural formula in samples is recalculated on the grounds of 23 oxygens. Cations per formula obtained by electron microprobe of these amphibole range from: $\mathrm{Si}=7.75-8.09$, $\mathrm{Na}=1.32-1.72, \mathrm{CaO}=0.32-0.67, \mathrm{Mg}=1.83-2.19, \mathrm{Al}=0.23-0.39$, and $\mathrm{Fe}^{3+}=1.26-1.88$. Low amounts of several trace element ( $\mathrm{Mn}$ and $\mathrm{Cr}$ ) are also present in the crystals. Magnesio-riebeckite is grouped as sodic types amphiboles according to [42,43]. The diagram [44] allowed us to classify all the analyzed samples as Magnesio-riebeckite (Figure 4).

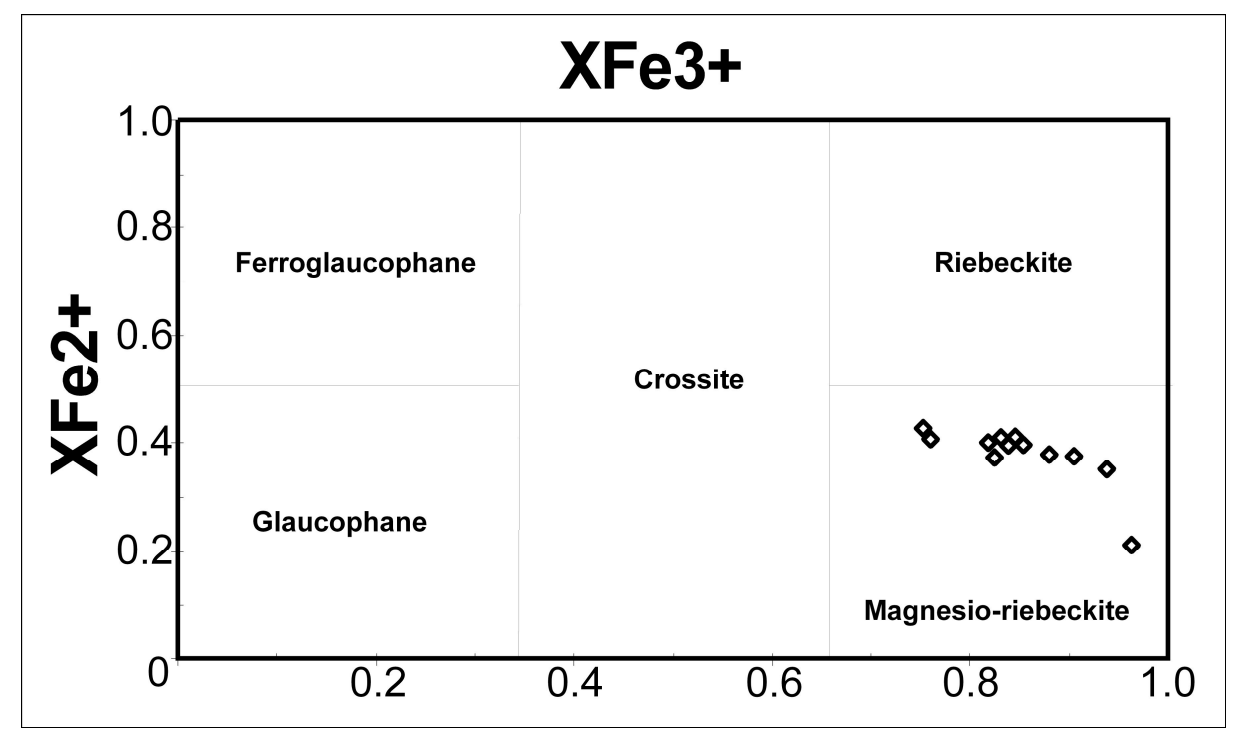

Figure 4. Amphibole classification diagram $[42,43]$.

The chlorite structural formula was recalculated on the basis of 14 oxygens. The chlorite is associated with the epidote crystals and occurs along amphibole. Chlorite shows high contents in 
$\mathrm{FeO}$ ranging between 24.05 to $26.50 \mathrm{wt} \%$ and $\mathrm{MgO}$ ranging between 16.08 to $18.10 \mathrm{wt} \%$; consequently, chlorite is classified as Fe-Mg chlorite. The composition of epidote crystals corresponds to epidote s.s. The epidote structural formula was recalculated on the basis of 12.5 oxygens and are recalculated to the formula $\mathrm{X}_{2} \mathrm{Y}_{3}(\mathrm{Si}, \mathrm{Al})_{3} \mathrm{O}_{12}(\mathrm{OH})$, assuming all the iron is ferric. Epidote crystals occur as inclusions in Magnesio-riebeckite crystals.

\section{Conclusions}

In the schists cropping out in the Mount Nandiniello area in the Pollino Unesco Global Geopark, fibrous minerals such as Magnesio-riebeckite, for the first time, were identified by cross-checking the data obtained through several analytical techniques. In this area, the ophiolitic rocks contain asbestos minerals. The most common are fibrous serpentine and amphiboles such as tremolite and edenite [2]. Schists of Mount Nandiniello showed that the samples have a high amount of fibrous Magnesio-riebeckite and is almost associated with other phases (glaucophane, chlorite, epidote, quartz, and stilpnomelane). Under optical microscope, Magnesio-riebeckite appears as needle-shaped crystals with dark green-black and bluish-green color. SEM observation allowed us to characterize the habit of Magnesio-riebeckite. Crystals appears with fibrous habit and size between 5-20 $\mu \mathrm{m}$ in length and diameter about $1 \mu \mathrm{m}$, respectively, comparable to regulated asbestos minerals with aspect ratio (length:diameter) major of 3:1.

EPMA and EDS analyses proved that $\mathrm{FeO}$ is abundant in the Magnesio-riebeckite crystals as compared with riebeckite from Alinci (Republic of Macedonia) [45]. In the Pollino Unesco Global Geopark, serpentinites and Magnesio-riebeckite schists are employed as civil constructions and building stones and this could lead to release of fibers in the air, of which the effects may be not negligible. It would be important to take into consideration the degree of risk of the presence of these minerals in the study area, as it could represent a potential hazard for human health, although Magnesio-riebeckite is currently not regulated as asbestos by either the European Parliament or the European Council of 27 March 2003. Further studies are able to establish the correlation between exposure and health effects. The identification by different analytical techniques in this area of fibrous minerals such as serpentine, tremolite, edenite, and now also Magnesio-riebeckite is important for public health and environmental protection [46]. In conclusion, we think that the mapping of these minerals and detailed field and laboratory analysis [47] are compulsory to improve our knowledge on the mode of occurrence of minerals, with size regulated by international normative definitions, in the rocks of the Pollino Unesco Global Geopark.

Author Contributions: Conceptualization, G.R. and S.L.; methodology (EPMA and SEM measurements on riebeckite crystals), S.L.; resources, G.R.; data curation, G.R., and S.L.; writing一original draft preparation, S.L. and G.R.; supervision, G.R.

Funding: This research was funded by a Giovanna Rizzo grant, RIL2016.

Acknowledgments: This work has received financial support from University of Basilicata. The Authors would like acknowledge the Editor, Academic Editor and the anonymous reviewer for their constructive review of the manuscript.

Conflicts of Interest: The authors declare no conflict of interest.

\section{References}

1. Bloise, A.; Punturo, R.; Catalano, M.; Miriello, D.; Cirrincione, R. Naturally occurring asbestos (NOA) in rock and soil and relation with human activities: The monitoring example of selected sites in Calabria (southern Italy). Ital. J. Geosci. 2016, 135, 268-279. [CrossRef]

2. Dichicco, M.C.; Paternoster, M.; Rizzo, G.; Sinisi, R. Mineralogical asbestos assessment in the southern Apennines (Italy): A review. Fibers 2019, 7, 24. [CrossRef]

3. Belluso, E.; Cavallo, A.; Halterman, D. Crystal habit of mineral fibres. In Mineral Fibres: Crystal Chemistry, Chemical-Physical Properties, Biological Interaction and Toxicity; Gualtieri, A.F., Ed.; Mineralogical Society of Great Britain and Ireland: Middlesex, UK, 2017; Volume 18, pp. 65-109. 
4. Bloise, A.; Ricchiuti, C.; Giorno, E.; Fuoco, I.; Zumpano, P.; Miriello, D.; Apollaro, C.; Crispini, A.; De Rosa, R.; Punturo, R. Assessment of Naturally Occurring Asbestos in the Area of Episcopia (Lucania, Southern Italy). Fibers 2019, 7, 45. [CrossRef]

5. Nichols, M.D.; Young, D.; Davis, G. Guidelines for geologic investigation of naturally occurring asbestos in California. In California Geological Survey Public Information Offices; Clinkenbeard, J.P., Churchill, R.K., Lee, K., Eds.; Special Publication, 2002; p. 124. Available online: http://www.consrv.ca.gov (accessed on 1 August 2019).

6. Bloise, A.; Critelli, T.; Catalano, M.; Apollaro, C.; Miriello, D.; Croce, A.; Barrese, E.; Liberi, F.; Piluso, E.; Rinaudo, C. Asbestos and other fibrous minerals contained in the serpentinites of the Gimigliano-Mount Reventino unit (Calabria, S-Italy). Environ. Earth Sci. 2014, 71, 3773-3786. [CrossRef]

7. Dichicco, M.C.; De Bonis, A.; Mongelli, G.; Rizzo, G.; Sinisi, R. $\mu$-Raman spectroscopy and X-ray diffraction of asbestos' minerals for geo-environmental monitoring: The case of the southern Apennines natural sources. Appl. Clay Sci. 2017, 141, 292-299. [CrossRef]

8. Burke, E.A.J.; Leake, B.E. "Named amphiboles", a new category of amphiboles. Can. Mineral. 2004, 42, 1881-1883. [CrossRef]

9. Hawthorne, F.C.; Oberti, R.; Harlow, G.E.; Maresch, W.V.; Martin, R.F.; Schumacher, J.C.; Welch, M.D. Nomenclature of the amphibole supergroup. Am. Mineral. 2012, 97, 2031-2048. [CrossRef]

10. Sauer, A. Ueber Riebeckit, ein neues Glied der Hornblendegruppe, sowie über Neubildung von Albit in granitischen Orthoklasen. Z. Dtsch. Geol. Ges. 1888, 40, 138-152.

11. Ogniben, L. Schema introduttivo alla geologia del confine calabro-lucano. Mem. Soc. Geol. Ital. 1969, 8, 453-763.

12. Patacca, E.; Scandone, P. Geology of the southern Apennines. Boll. Soc. Geol. Ital. 2007, 7, 75-119.

13. Knott, S.D. The Liguride Complex of Southern Italy-A Cretaceous to Paleogene accretionary wedge. Tectonophysics 1987, 142, 217-226. [CrossRef]

14. Bonardi, G.; Amore, F.O.; Ciampo, G.; De Capoa, P.; Miconnét, P.; Perrone, V. Il Complesso Liguride Auct.: Stato delle conoscenze attuali e problemi aperti sulla sua evoluzione Pre-Appenninica ed i suoi rapporti con 1'Arco Calabro. Mem. Soc. Geol. Ital. 1988, 41, 17-35.

15. Mazzeo, F.C.; Zanetti, A.; Aulinas, M.; Petrosino, M.; Arienzo, I.; D’Antonio, M. Evidence for an intra-oceanic affinity of the serpentinized peridotites from the Mt. Pollino ophiolites (southern Ligurian Tethys): Insights into the peculiar tectonic evolution of the southern Apennines. Lithos 2017, 284, 367-380. [CrossRef]

16. Tortorici, L.; Catalano, S.; Monaco, C. Ophiolite-bearing mélanges in southern Italy. Geol. J. 2009, 44, $153-166$. [CrossRef]

17. Spadea, P. Continental crust rock associated with ophiolites in Lucanian Apennine (Southern Italy). Ofioliti 1982, 7, 501-522.

18. Spadea, P. Calabria-Lucania ophiolites. Boll. Geofis. Teor. Appl. 1994, 36, 271-281.

19. Knott, S.D. Structure, kinematics and metamorphism in the Liguride Complex, Southern Apennine, Italy. J. Struct. Geol. 1994, 16, 1107-1120. [CrossRef]

20. Monaco, C.; Tortorici, L. Tectonic role of ophiolite-bearing terranes in the development of the southern Apennines orogenic belt. Terra Nova 1995, 7, 153-160. [CrossRef]

21. Monaco, C.; Tortorici, L.; Morten, L.; Critelli, S.; Tansi, C. Geologia del versante Nord-orientale del Massiccio del Pollino (Confine calabro lucano). Nota illustrativa sintetica alla scala 1:50.000. Boll. Soc. Geol. Ital. 1995, 114, 277-291.

22. Rizzo, G.; Sansone, M.T.C.; Perri, F.; Laurita, S. Mineralogy and petrology of the metasedimentary rocks from the Frido Unit (southern Apennines, Italy). Period. Mineral. 2016, 85, 153-168.

23. Spadea, P. Contributo alla conoscenza dei metabasalti ofiolitici della Calabria Settentrionale e Centrale e dell'Appennino Lucano. Rend. Soc. Ital. Mineral. Petrol. 1979, 35, 251-276.

24. Sansone, M.T.C.; Rizzo, G.; Mongelli, G. Petrochemical characterization of mafic rocks from the Ligurian ophiolites, southern Apennines. Int. Geol. Rev. 2011, 53, 130-156. [CrossRef]

25. Sansone, M.T.C.; Prosser, G.; Rizzo, G.; Tartarotti, P. Spinel peridotites of the Frido unit ophiolites (southern Apennines Italy): Evidence for oceanic evolution. Period. Mineral. 2012, 81, 35-59. [CrossRef]

26. Sansone, M.T.C.; Tartarotti, P.; Prosser, G.; Rizzo, G. From ocean to subduction: The polyphase metamorphic evolution of the Frido unit metadolerite dykes (southern Apennine, Italy). Multiscale structural analysis devoted to the reconstruction of tectonic trajectories in active margins. J. Virtual Explor. 2012, 41,3. [CrossRef] 
27. Sansone, M.T.C.; Rizzo, G. Pumpellyite veins in the metadolerite of the Frido Unit (Southern Apennines, Italy). Period. Mineral. 2012, 81, 75-92. [CrossRef]

28. Dichicco, M.C.; Laurita, S.; Paternoster, M.; Rizzo, G.; Sinisi, R.; Mongelli, G. Serpentinite carbonation for $\mathrm{CO}_{2}$ sequestration in the southern Apennines: Preliminary study. Energy Proced. 2015, 76, 477-486. [CrossRef]

29. Rizzo, G.; Canora, F.; Dichicco, M.C.; Laurita, S.; Sansone, M.T.C. P-T estimates from amphibole and plagioclase pairs in metadolerite dykes of the Frido unit (southern Apennines-Italy) during the ocean-floor metamorphism. J. Mediterr. Earth Sci. 2019, 11. [CrossRef]

30. Laurita, S. Il Prisma di Accrezione Liguride Affiorante al Confine Calabro-Lucano: Studio Termocronologico e Strutturale. Ph.D. Thesis, University of Basilicata, Potenza, Italy, 2009.

31. Vitale, S.; Fedele, L.; D'Assisi Tramparulo, F.; Ciarcia, S.; Mazzoli, S.; Novellino, A. Structural and petrological analyses of the Frido Unit (southern Italy): New insights into the early tectonic evolution of the southern Apennines-Calabrian Arc system. Lithos 2013, 168, 219-235. [CrossRef]

32. Laurita, S.; Prosser, G.; Rizzo, G.; Langone, A.; Tiepolo, M.; Laurita, A. Geochronological study of zircons from continental crust rocks in the Frido Unit (Southern Apennines). Int. J. Earth Sci. 2014, 104, 179-203. [CrossRef]

33. Beccaluva, L.; Macciotta, G.; Spadea, P. Petrology and geodynamic significance of the Calabrian-Lucanian ophiolites. Rend. Soc. Ital. Mineral. Petrol. 1982, 38, 973-987.

34. Laurita, S.; Rizzo, G. Blueschist metamorphism of metabasite dykes in the serpentinites of the Frido Unit, Pollino Massif. Rend. Online Soc. Geol. Ital. 2018, 45, 129-135. [CrossRef]

35. Cavalcante, F.; Belviso, C.; Laurita, S.; Prosser, G. P-T constraints from phyllosilicates of the Liguride complex of the Pollino area (southern Apennines, Italy): Geological inferences. Ofioliti 2012, 37, 65-75.

36. Franzini, M.; Leoni, L.; Saitta, M. A simple method to evaluate the matrix effects in X-ray fluorescence analysis. X-Ray Spectrom. 1972, 1, 151-154. [CrossRef]

37. Franzini, M.; Leoni, L.; Saitta, M. Revisione di una metodologia analitica di fluorescenza-X basata sulla correzione completa degli effetti di matrice. Rend. Soc. Ital. Mineral. Petrol. 1975, 31, 365-378.

38. Andreozzi, G.B.; Pacella, A.; Corazzari, I.; Tomatis, M.; Turci, F. Surface reactivity of amphibole asbestos: A comparison between crocidolite and tremolite. Sci. Rep. 2017, 7, 14696. [CrossRef] [PubMed]

39. Hardy, J.A.; Aust, A.E. Iron in asbestos chemistry and carcinogenicity. Chem. Rev. 1995, 95, 97-118. [CrossRef]

40. Kamp, D.W. Asbestos-induced lung diseases: An update. Transl. Res. 2009, 153, 143-152. [CrossRef] [PubMed]

41. Liu, G.; Cheresh, P.; Kamp, D.W. Molecular Basis of Asbestos-Induced Lung Disease. Ann. Rev. Pathol. Mech. Dis. 2013, 88, 161-187. [CrossRef] [PubMed]

42. Leake, B.E.; Woolley, A.R.; Arps, C.E.; Birch, W.D.; Gilbert, M.C.; Grice, J.D.; Hawthorne, F.C.; Kato, A.; Kisch, H.J.; Krivovichev, V.G.; et al. Nomenclature of amphiboles: Report of the subcommittee on amphiboles of International Mineralogical Association Commission on New Minerals and Mineral Names. Mineral. Mag. 1997, 61, 295-321. [CrossRef]

43. Leake, B.E.; Woolley, A.R.; Birch, W.D.; Burke, E.A.J.; Ferraris, G.; Grice, J.D.; Hawthorne, F.C.; Kisch, H.J.; Krivovichev, V.G.; Schumacher, J.C.; et al. Nomenclature of amphiboles: Additions and revisions to the International Mineralogical Association's amphibole nomenclature. Am. Mineral. 2004, 89, 883-887.

44. Evans, B.W. Phase relations of epidote-blueschists. Lithos 1990, 25, 3-23. [CrossRef]

45. Sijakova-Ivanova, T.; Robeva-Cukovska, R.; Javanoski, F.; Kareski, S. Mineralogical characterization of riebeckite from Alinci, Republic of Macedonia. Geol. Maced. 2018, 32, 75-87.

46. Punturo, R.; Ricchiuti, C.; Bloise, A. Assessment of Serpentine Group Minerals in Soils: A Case Study from the Village of San Severino Lucano (Basilicata, Southern Italy). Fibers 2019, 7, 18. [CrossRef]

47. Militello, G.M.; Bloise, A.; Gaggero, L.; Lanzafame, G.; Punturo, R. Multi-Analytical Approach for Asbestos Minerals and Their Non-Asbestiform Analogues: Inferences from Host Rock Textural Constraints. Fibers 2019, 7, 42. [CrossRef]

(C) 2019 by the authors. Licensee MDPI, Basel, Switzerland. This article is an open access article distributed under the terms and conditions of the Creative Commons Attribution (CC BY) license (http://creativecommons.org/licenses/by/4.0/). 